\title{
Theodicy of Jean-Jacques Rousseau
}

\author{
Claudio Tugnoli \\ Adjunct Professor of Moral Philosophy - University of Trento, Italy
}

doi: 10.19044/esj.2016.v12n29p10 URL:http://dx.doi.org/10.19044/esj.2016.v12n29p10

\begin{abstract}
Throughout all of Rousseau's works there is tension between argumentation and feeling, speculation and intuition, reason and conscience. Reason binds men when they think correctly, but divides them and opposes one to the other when they place it at the service of self-interest, of ambition and of the will to prevail. Conversely, the universality of conscience is immediate and transparent: it transmits the truth of the existence of God, of the freedom of men, of the distinction between good and evil, as well as of the universal principles that are at the roots of human action and of the virtues honoured by all human societies, despite the differences of particular legislations. Mankind possesses an innate and intuitive conscience of the fundamental principles by which its conduct must be inspired. Were we to consider human actions only according to the criterion of physical need, of causality and of movement, vices and virtues would disappear and terms like morality and honesty would have no meaning. But each one of us perceives from within that this is not the case. We feel that moral good and evil are more real than anything else, without any need whatsoever to prove it. To obey the conscience one has of good and of evil without human mediation means to reject the dogmatic formalism of religions as well as the vanity of philosophical disputes. Every human being, however, is inserted into a national community. What should the state's attitude be vis-à-vis religion? Rousseau indicates two paths. The first consists in establishing a purely civil religion that admits only those dogmas that are truly useful to society. Rousseau highlights the contradiction of a Christian religion that, although it is the religion of peace par excellence, fuels continuing bloody clashes among men due to a dogmatic theology that is totally alien to the essence of the Gospel and extremely hazardous for the life of the State. The second path consists in allowing Christianity to retain its authentic spirit, its freedom from any material constraint, without any obligations other than those of individual conscience. The Christian religion has such a pure and noble moral that it cannot but benefit the State, as long as one does not expect to make it part of the constitution.
\end{abstract}


Keywords: Jean-Jacques Rousseau, moral conscience, feeling of good and evil, existence of God, meaning of Gospel, indisputable freedom of man

\section{The Fragment On God}

According to Pierre Burgelin one should accept Théophile Dufour's theory that the fragment was composed in 1735, when Rousseau was about 23 years old (Burgelin 1952). The fragment On God demonstrates that, for Rousseau, the existence of God is not an abstract speculative issue but rather is closely connected to the problem of evil and of freedom. Our conviction that a God exists, Rousseau argues, is incompatible with the principles that in fact inspire our conduct in this life ${ }^{6}$. The notion of God is inseparable from the idea of eternal and of infinite. What else is infinite in God other than intelligence, wisdom, justice and power? Rousseau believes that it would be much easier to eradicate from one's inner self the feeling of the existence of God rather than conceive it without assigning to it the attributes mentioned above and that, taken all together, represent the only way in which we can conceive God Himself. Thus, if the power of God is infinite, it follows that this power necessarily extends to the entirety of our being. And since God is the source of all wisdom, He will expect men to govern themselves according to the principles that He has placed in their spirit as the basis of virtue and of religion (Rousseau 2012, XVII, 439-440).

Should God have used his infinite power to force men to act according to his principles, he would have been legitimated in doing so by his own infinite wisdom, since men's obedience of his decrees would have made them virtuous. If instead one looks at how men do behave, one sees immediately that they do not follow the divine orders that God himself has placed in their hearts. The obvious conclusion is that God has not used His infinite power to force them to obey his decrees, given that, obviously, if he had indeed done so, no one could have evaded His will because God's power is infinite. Rousseau implicitly reasons that if God had forced men to follow his decrees, however, moral perfection would not have been the result of their effort and commitment. They could not have claimed merit for the virtue they would have given proof of, and therefore they would not have been virtuous either. The obstacle to virtue could not be external, however (only the help in becoming perfectly virtuous could come from the exterior), since the impossibility of overcoming the obstacle in doing good would have excused and removed the vice as such. Thus, the obstacle would have had to

\footnotetext{
${ }^{6}$ Masson attributes an autobiographical meaning to this statement, which he finds banal. In fact, in the same year (1735), Rousseau wrote to his father $(\mathrm{X}, 12)$ : «J'ai de la religion et je crains Dieu; d'ailleurs, sujet à d'extrêmes faiblesses et rempli de défauts plus qu'aucun autre homme du monde, je sens combien il y a de vices à corriger chez moi» (Masson 1970, 91).
} 
be internal and subjective. It was necessary for the difference between the divine decrees and the principles inspiring the actions of men to be exclusively a result of their free will. Evil is nothing but the existence of evil beings, to the point that one can say that, already in this fragment, Rousseau better specifically defines evil "in se" with the exact term of moral evil. The existence of wicked men does not disprove the existence of God or His infinite power. In just a few words Rousseau shows that, instead, the evil beings, with their very existence, show God's will to allow mankind the final decision, i.e. absolute autonomy in the intended use of their freedom.

\section{The Two Prayers}

Dufour's theory that the two prayers dating back to Rousseau's youth were written in Charmettes in 1738 or 1739 was taken up by Courtois (Courtois 1969, 1763-1764). Pierre-Maurice Masson provided a commentary (Masson 1970, 120-128). In a passage from the Confessions, Rousseau tells us that, when he was in Charmettes, he would rise before dawn and take a walk, elevating a prayer to the author of the beautiful sights his eyes were enjoying. Rousseau confesses he never prayed in his bedroom because he felt that the walls and everything else made by man acted as an obstacle between him and God. His desire was to relate to God directly (Rousseau 2012, I, 339). In his prayers to God, Rousseau expressed more his admiration and contemplation than requests, because he knew that to obtain the true gifts from God it was not enough to request them, you had to deserve them (Rousseau 2012, XVII, 444-445). Rousseau asks God for what he already knows he possesses within him, what he knows he has received from Him. Indeed, God has placed in his heart the principles of his wisdom and the freedom to be inspired by them in his actions. Man alone is responsible for taking the initiative in realising virtue. So, in actual fact, Rousseau's prayer is an expression of praise of God.

Innocence and virtue are attained by sacrificing the artificial status in which man finds himself in civil life. All that mankind has built in the centuries is nothing but a tragic and fatal shift from the original perfection in which men and nature find themselves when coming out of the hands of God. In the Prayer we find confirmed the affective tonality that Rousseau expresses in the Confessions: the prayer to a God that is both to be feared and merciful is essentially a way of expressing thanks for all the good received, i.e., in the right order: birth, the rational soul, the knowledge of God. God is also thanked, however, for having seen to human needs, for having cured infirmity and finally for having united the ones with the others. Rousseau especially asks God to point him in the direction of virtue and not to make him so unhappy as to doubt the very existence of God (Rousseau 2012, XVII, 445). 
His acknowledgement of Divine providence is reiterated in the second prayer, in contrast with the negation of Divine intervention in history that he states elsewhere. The God Rousseau turns to with this prayer is at the same time infinitely powerful and good. With respect to this God, the existence of evil men is not at all a contradiction, precisely because, according to Rousseau, the only evil worthy of being taken into consideration is moral evil, subject only to the free will of men. Rousseau praises God for having created him from nothing (God can create from nothing a living being that by itself is incapable of giving itself life or of coming from nothing), for having given him a rational soul, for having impressed in his heart laws that, when put in practice, are a guarantee of eternal joy and tend to bring joy in this life too (Rousseau 2012, XVII, 446). In this second prayer, for the most part a praise to God, Rousseau once again asks for mercy for his weaknesses and for help in fighting the vices in which his weaknesses have dragged him. He confesses that all of the pleasures that his abandonment of wisdom has led him to turned out to be painful and hateful illusions (Rousseau 2012, XVII, 447). Most of all, he asks for forgiveness for not having been able to put to good use his life, his freedom and all of the means God has given him, including reason, in order to acquire virtue and to become worthy of eternal joy. Repentant, Rousseau promises to follow righteousness, relating all of his actions to God himself, to meditate Him, to bless Him, to serve Him, to fear Him. He also promises to love his neighbour, to help the wretched and the unfortunate. Rousseau promises moderation and purity in his every action, control of anger and of speech. The only pleasures he will allow himself will be those allowed by virtue. He shall detach himself from the world and from its comforts, to dedicate himself only to divine perfection. With evangelical purpose he shall forgive everyone, in turn staying away from offending anyone. Finally, in submitting himself to God and to His supreme will, Rousseau states his intention to prepare himself for death and for the judgement to which his conduct will be subjected. In preparing himself to live his life in the most perfect obedience of divine law, Rousseau declares he is aware that, without the grace of God, no project can be accomplished and any intent is destined to fail.

\section{Letter to François-Marie Arouet dit Voltaire (18 August 1756)}

Why is it that the Lisbon earthquake of 1755 has stuck in mankind's memory more than any other disaster before and after it? Why did it strike the contemporaries as something absolutely "unique and surprising"? ${ }^{7}$ Just ten years before, in October of 1746, a terrible earthquake had flattened the city of Lima, the capital of Peru, killing twenty thousand people, while the

\footnotetext{
${ }^{7}$ According to the definition by Walter Benjamin (Tagliapietra 2004, IX).
} 
Chinese earthquakes of Qili and Peking that had occurred a few decades before then had claimed the lives of two hundred thousand people. The earthquake, to this day declared the bloodiest of them all, that hit China in the mid- $16^{\text {th }}$ century, killed eight hundred and thirty thousand people, according to the chronicles of the time. What made the Lisbon earthquake so memorable was its position. It became unique and unrepeatable because it hit Lisbon, namely Atlantic Europe. It wasn't an exotic cataclysm, the more extreme the more marginal. News of the Lisbon earthquake spread like wildfire throughout Europe and caused a vast multitude of writings. The earthquake, that struck on the day of All Saints of 1755, produced objectively disturbing effects. Walter Benjamin refers that it was felt in the whole of Europe and all the way to Africa. The tsunami was experienced from Finland to Indonesia (Tagliapietra 2004, XIII). It has been calculated that with its farthest waves it covered a surface two and a half million kilometers wide.

Voltaire learned about the Lisbon catastrophe on November $23^{\text {rd }}$. Deeply perturbed by the news, he wrote off in less than twenty days the 234 verses of his Poem on the Lisbon Disaster that, published on April $1^{\text {st }}, 1756$, was enormously successful and underwent many reprints in a very short time. Voltaire's poem is an accusation against God and a lecture against optimism. The topic is the Epicurean dilemma, frequently discussed by philosophers in anti-theologian terms. Epicurus' formidolosum argumentum was presented by Caecilius Firmianus Lactantius in chapter XIII of the De Ira Dei (Migne 1841-1864, 7, coll. 77-146, 121A-B) and can be schematically illustrated as follows (Tagliapietra 2004, 37):

\begin{tabular}{|c|c|c|}
\hline & $\begin{array}{c}\text { God does not want to } \\
\text { remove evil }\end{array}$ & God wants to remove evil \\
\hline $\begin{array}{c}\text { God is unable to remove } \\
\text { evil }\end{array}$ & $\begin{array}{c}\text { God is neither benevolent } \\
\text { nor omnipotent }\end{array}$ & God is not omnipotent \\
\hline God is able to remove evil & God is not benevolent & Then why does evil exist? \\
\hline
\end{tabular}

By picking up Epicurus' formidolosum argumentum, Voltaire is filled with indignation before this image of a God that remains indifferent to the death and suffering for which instead He should feel responsible. Voltaire simply cannot tolerate this merciless, calm and indifferent God. God's silence seems unacceptable to him, just like he cannot stand "Job's friends", i.e. all of the optimists of every era that explain divine inaction with man's guilt. Voltaire asks that all of "Job's friends" be silent, so that all of the unfortunate, the victims of catastrophes, may lift their innocent cry.

In response to Voltaire's sending him his two poems Sur la loi naturelle and Sur le désastre de Lisbonne, Rousseau writes to the author of Candide a subtle letter that certainly must have surprised the recipient. In his Poem on the Lisbon Disaster Voltaire uses the earthquake as an argument to 
ridicule the optimism professed by Pope and by Leibniz, who say that all is good despite the most overwhelming evidence to the contrary. But, Rousseau objects, in this manner mankind's misery is exacerbated to such an extent as to become unbearable. Imagining that Voltaire had displayed irremediable pessimism, almost as if in this way the unhappy may set their minds at rest thanks to the demonstration that all is evil, Rousseau warns Voltaire that exactly the opposite happens: «This optimism which you find so cruel yet consoles me amid the very pains which you depict as unbearable» (Rousseau 2012, XVII, 474). Rousseau finds Voltaire's poem unacceptable because it does not allow the suffering man any hope vis-à-vis an evil that God himself does not remove from the world despite his omnipotence. Rousseau admits to having represented human misery in the Discours sur l'origine et les fondements de l'inégalité parmi les hommes (published in Amsterdam in 1755), but at least he did so not to prove their inevitability, but rather to teach men that they are the ones responsible for their misfortunes and to show them how to overcome this state of affairs. Rousseau once again makes a distinction between physical evil and moral evil. The origin of moral evil must be sought for in the free man who has achieved a certain degree of perfection and at the same time of corruption ${ }^{8}$.

Ultimately, man is also responsible for natural evil. Physical pains are inevitable, because they are generated by the structure of matter; or apparent, such as death, that is an evil only for the way in which it is awaited and one prepares for it; or, finally, it is evitable, just like most illnesses, that are the consequences of the enfeeblement of the organism caused by our abandoning the simple and solitary lifestyle of our origins. Following a line of reasoning that later would have been adopted by Kant and that today represents the fundamental principle of prevention in the field of civil defense, Rousseau argues that, though the Lisbon earthquake was inevitable, its effects would have been drastically reduced had the residential housing been more carefully planned (lower buildings, better distributed over the land, etc.). Moreover, one must consider that premature death is not always an absolute evil. To the contrary, many of the unfortunate who died under the rubble may have avoided greater misfortunes, such as for example dying pestered by notaries and heirs, or killed in their beds by arrogant and unscrupulous physicians. The natural miseries that we suffer, Rousseau concludes, are much less cruel than those we cause ourselves with our choices. The miseries caused by man could be much worse (Rousseau 2012, XVII, 476-477). Life becomes an unbearable weight for those who have moved away from nature, mostly men of letters, the most sedentary, the most inclined to reflection and,

${ }^{8}$ «Je ne vois pas qu'on puisse chercher la source du mal moral ailleurs que dans l'homme libre, perfectionné, partant corrompu» (Rousseau 2012, XVII, 476) 
in consequence, the most unhappy. The philosophers, because they have lost the capacity to feel the joy of living, slander life with the argument that death is inevitable. Cato shows with his life that the wise man can decide to give up life with dignity, but that the misfortune that comes our way does not make life a "bad present".

Rousseau states his disagreement with Voltaire as regards a theory supported by de Crousaz, citing which Voltaire says that it is not true that if one single atom were removed from the world, the world would no longer exist; and that nature is not subject to any precise measure, precise form or unfailing, rigorous and predetermined law. According to Rousseau, the irregularities mentioned by Voltaire in support of his thesis on nature's imprecision were certainly due to laws still unknown at that time. Conversely, one would have to admit the possibility of effects without causes, something that no philosophical system acknowledges. Two balanced weights, one of which hiding a magnet, would show a manifest behaviour, in response to an extra force or an extra weight, that would apparently confirm the possibility of there being a cause without an effect and an effect without a cause. But to the person who then discovers the existence and action of the magnet, the precision and rigour of nature would be confirmed. Rousseau considers the example of the two balanced weights as paradigmatic and applicable in general to the entire world of phenomena, thus confirming his deterministic view of material nature, in perfect agreement with the metaphysical dualism expressed in his Letter to $M$. de Franquières and in the Profession of Faith. But here the reader also extracts an implicit answer to the question of the earthquake and of disasters in general. Indeed, nature is a perfect mechanism, the processes of which can be understood only in the light of the principle of causality. Thus, there is no Providence that governs nature ${ }^{9}$. After all, Voltaire's pessimism is a reproach to the divinity and reveals a totally pre-rational concept of nature. Nature does all that it must do and some of its phenomena are interpreted from a theological viewpoint only because we ignore the laws that, sooner or later, will be discovered to be the origin of such singular events.

Voltaire's mistake, Rousseau believes, consists in the claim that mankind's future is more dear to God than that of any other being, intelligent

${ }^{9}$ One would be tempted to detect a contradiction between this theory and the position Rousseau defends in the Profession of Faith, where he attributes the movement of matter, ultimately, to a cause that is God Himself. The contradiction is only apparent, however, because God moves nature according to a necessary order that $\mathrm{He}$ could violate, if $\mathrm{He}$ wished to, but that He does not violate in order to be coherent with Himself. In short, although God is the ultimate cause of movement, the natural processes occur based on an absolutely inviolable necessity, in a state of perfect autonomy that makes the moral classes of good and evil inapplicable. 
or not, dispersed in the universe. Voltaire's anthropocentric view is the expression of a vaniloquent egocentrism that fails to take into account the totality of the universe and expects to judge everything based on the subjective condition of a few individuals. Instead, nature should be considered in its entirety: without the totality category, the comprehension of both nature and society is destined to fail. From the viewpoint of totality, even the most catastrophic of events is capable of causing positive effects: «If, in the system of the universe, it is necessary to the preservation of mankind that there be a cycle of substance between man, animals and vegetation, then one individual's particular evil contributes to the general good: I die, I am eaten by worms, but my children, my brothers will live as I have lived»(Rousseau 2012, XVII, 486). Rousseau makes a distinction between general and individual evil. Although the latter has never been denied by any philosopher, when it comes to the former it is necessary to state whether the existence of the universe is a good thing per se. The addition of an article is therefore justified: we will not say all is good (tout est bien), but rather the whole is good (le tout est bien) or all is good for the whole (tout est bien pour le tout).

Rousseau accuses priests and the devout of having promoted a faulty type of theology of nature by attributing to divine Providence, rather than to nature, effects that would have occurred even without divine intervention. By interpreting nature's phenomena as beneficial for the good or damaging for the wicked, priests favour an egotistical and anthropomorphic perception of nature and Providence. Philosophers are scarcely more reasonable than priests when they accuse God for every little thing, like when they «cry out that all is lost when they have a toothache, or are poor, or get robbed, and hold God responsible, as Seneca says, for looking after their luggage» (Rousseau 2012, XVII, 488-489). Whichever the facts nature gives rise to, priests and philosophers express their views in opposite manners: «Providence is always right among the devout, and always wrong among the philosophers» (Rousseau 2012, XVII, 489). No one dwells on whether it is right or wrong, because everything in nature occurs according to a single law that makes no exceptions whatsoever. According to Rousseau, in the eyes of God the particular has no value, in the same way as the particular will does not and must not bear any weight compared to the general will. One therefore must free God from the misunderstandings and accusations the devout and the philosophers soil Him with, because one cannot state the existence of God and then attribute to Him actions unworthy of Him. In this manner, Rousseau's theological coherence comes full circle: «If God exists, $\mathrm{He}$ is perfect; if $\mathrm{He}$ is perfect, $\mathrm{He}$ is wise, powerful, and just; if $\mathrm{He}$ is wise and powerful, all is good; if He is just and powerful, my soul is immortal; if 
my soul is immortal, thirty years of life are nothing to me and are perhaps necessary to the preservation of the universe» (Rousseau 2012, XVII, 490). But God exists. His existence cannot be proven definitely by reason, by the objections and by the answers to said objections, because disputes are based on the knowledge of things about which men have no true idea. And if reason is insufficient, faith must take over, because «the state of doubt is too violent a state for my soul» (Rousseau 2012, XVII, 491) ${ }^{10}$.

${ }^{10}$ A God limited by laws becomes a real contradiction: an impotent God who couldn't be trusted to keep his promise to make the Hebrew people the elected people. The Book of Job should have resolved that paradox. The story of Job seems incomprehensible if one takes the point of view of the citizens of a modern state, who expect that the sovereign will respect his contractual obligations and they don't award him any powers to decide by himself, without consulting them and over and above the prevailing laws. Carl Schmitt repeats the judgment of the Book of Job, according to which it is impossible to trust any inviolable rule, law or principle. The sovereign as such is he who holds the power of exemption and can establish the state of exception. The power to impose respect for shared rules presupposes the prerogative to suspend or invalidate them. Without this prerogative no power exists, but only impotence. Bauman cites Agamben, who grasped the absence of contradiction between establishing a rule and making an exception. This therefore is the truth behind power $(\mathrm{Z}$. Bauman - G. Dessal, El retorno del péndulo. Sobre psicoanálisis y el futuro del mundo liquido, 2014, trad. it., Il ritorno del pendolo. Psicoanalisi e futuro del mondo liquido, edited by R. Mazzeo, Erickson, Trento 2015, 80). The story told in the book of Job represents a challenge to the capacity of the comprehension of human beings, who await the restitution and respect of the law. These same theologists, in the book of Job, insinuate that Job must have committed a serious sin that justifies the ruin into which Job has fallen, thus demonstrating that they believe firmly in the connection between sin and punishment, virtue and recompense, in the only way in which, to their eyes, makes it possible to justify unspeakable sufferings that are inflicted on an apparently just and God-fearing man. But Job, despite protesting his innocence and good faith, knows that when it comes to God, no rule holds water. Job couldn't have known, comments Bauman, that in the coming centuries all those who had aspired to an absolute power, next to the divine omnipotence, would have easily utilised the unforeseeability and capricious discretion as massly efficient tools to obtain obedience and submission amongst their subjects. Bauman cites the work of Susan Neiman, Evil in modern thought: an Alternative History of Philosophy (2003) and JeanPierre Dupuy, Pétite Métaphysique des tsunamis (2007), which suggested that the Lisbon earthquake of 1755, with its earthquakes, fires and tsunamis in rapid succession, would have signalled the beginning of the modern philosophy of evil, which implies the clear separation between natural disasters and moral evil: the former conceived as being dominated by a blind coincidence that depends neither on God, nor on men, whereas the latter conceived the only evil that humans have the capacity to avoid being characterized by intentionality. According to Neiman, starting with Lisbon, natural evil is devoid of intention, as opposed to moral evil that is characterized by being intentional and deliberate. According to Dupuy, the most modern amongst the participants of the debate was Rousseau with his open letter to Voltaire. Here Rousseau continues to state that the fault - not of the disaster, but of its catastrophic consequences - must be attributed to human beings and not to nature. According to Rousseau the catastrophe was the result of man's short-sightedness and not the blindness of nature. If the dwellings had been distributed better across the land and had better anti-seismic measures been adopted, the disaster wouldn't have had such catastrophic 
Rousseau certainly concedes that Voltaire is right on many points. Like Voltaire, he says he is indignant about the fact that each one's faith is not perfectly free and that someone may claim the right to subordinate reason to authority, acknowledging the right of the State to control consciences. Anticipating the theories championed in the last part of the Social Contract, Rousseau admits that governments should limit their sphere of influence to civil duties and have no right to prescribe any positive precepts on how each one must serve God. Laws may impose a sort of profession of faith but, with the exclusion of the principles of morality and natural law, this profession must be purely negative, it must defend society from religions that attack its foundations and threaten the peace of the State. The profession of faith includes several dogmas that should be prohibited: intolerance and fanaticism (the intolerant imagines that it is impossible to be a good man without believing what he believes). A State can exist only if several positive social principles are complied with; these are listed in the Social Contract IV, 8: the existence of a mighty, intelligent and beneficent divinity,

consequences or, perhaps, wouldn't even have happened. Therefore the Lisbon disaster, according to Rousseau, was caused by the improvidence and greed of human beings, exactly as we today could complain about the fact that, in the case of an unforeseeable eruption of an unheard of duration and intensity of Vesuvius or Etna, the majority of deaths would be the consequence of the brainless construction of numerous dwellings almost on the rim of volcanic craters. The modern conception of evil as an essentially and exclusively moral evil, however, hasn't solved the question as far as the optimism with which it was inaugurated is concerned. The distinction between man and nature represents a success, but their separation, as Auschwitz has shown, is neither easy nor definitive. The identification of human responsibilities does not determine automatically the prevention of either moral evil or of suffering that nature can scatter at will with total indifference. «In Lisbon, humankind loses faith in himself», comments Neiman cited by Bauman. With Lisbon the awareness of the futility of the traditional theodicy began, according to which «natural disasters that fall upon humanity are the same punishments inflicted by God (at the same time supreme ethical legislator, final court of justice and executive branch of moral law) to sinners» (Z. Bauman G. Dessal, El retorno del péndulo. Sobre psicoanálisis y el futuro del mundo liquido, cit., 84). The blind frequency with which evil pervaded the world could not be reconciled with the combination of the omnipotence and benevolence attributed to the Creator and Sovereign of the world. It didn't add up, but to make it do so, one tried to load the shoulders of human beings with the entire responsibility of the evils that affect them. The finitude, pain and death ceased to be considered as evil, given that a justification could be found in the context of universal nature, as opposed to the theodicy that aimed to identify the cause of death and suffering in the original sin and individual sins. Max Weber would have removed the contradiction of the theodicy through his concept of disenchantment or loss of divinity, that strips nature of her divine cloak, of subjectivity capable of benevolence or malignancy. "However, warns Bauman, Nature wasn't stripped of her subjectivity in order to restore and safeguard the subjectivity of God, but rather to prepare the way for a deification of his human subject» (Z. Bauman - G. Dessal, El retorno del péndulo. Sobre psicoanálisis y el futuro del mundo liquido, cit., 85). 
possessed of foresight and providence; the life to come, the happiness of the just and the punishment of the wicked; the sacredness of the social contract and the laws.

The lack of comprehension between Rousseau and his contemporaries is largely due to the singularity of his position regarding the revelation and, more in general, the question of religion. Unlike most of his peers who contested religion on the basis of theoretical motivations and who, by rejecting dogmas on the grounds of irrationality, also do away with religion as such, Rousseau places in the foreground the natural religion that religion that each one of us feels in his/her own heart in the immediate and universal form of duties to be accomplished. Dogma is worth nothing, morality is everything and God demands that man, in charge of his own actions, pursue virtue (Rousseau 1969, IV, 1077).

God immediately reveals Himself to the human conscience as the indisputable source of the notions of good and evil that each one of us learns within himself without the need to think. The relationship between man and God is primary, it precedes any specific cult, it represents the reference by which one judges every historical revelation. The subjective starting point is not an abstract principle or a rationally demonstrable truth, but rather the immediate, instinctively irrefutable certainty of one's own freedom: man feels he is the author of his own actions and thus is free from the moment in which he feels within himself (and cannot but feel) the discrepancy between the action he commits and the principles to which he should conform. The moral sphere in which God reveals Himself immediately to the heart of men subtracts itself a priori from any analysis by the formal reason and cannot be subjected to any skeptic criticism. Men shall have to answer for their actions, not for what they have believed in or thought, since they possess the intuition of good and evil but not an infallible knowledge of truth and untruth (Rousseau 1969, IV, 1077). In fact, what could be more unjust than to expect perfect knowledge in mankind when it cannot achieve such a goal because it has not been endowed with the faculty to achieve it? So, undoubtedly, if one were to choose between being virtuous without believing in anything, and having a dead faith without results, one should select the former (Rousseau 1969, IV, 1078).

The religion of the heart, therefore, has precedence over positive revelation. The former is synthetic, the latter analytical. The former is all one with man's sensitivity and action, the latter distracts from good and from virtue, demanding the manifestation of a purely exterior faith, of arbitrary cults and formal behaviours, more suitable for gratifying and reassuring the hierarchy of the Church and the political powers than for generating peace in the heart, true wisdom, authentic virtue and the salvation of humanity. No authority can perform inspections or expect individuals to conform to some 
revealed religion. Governments must restrict themselves to demanding the performance of civic duties. In contrast with Thomas Hobbes, Rousseau argues that when a man serves the state well, he owes no one an account of how he serves God (Rousseau 1969, IV, 1078).

\section{The Moral Letters}

The year 1757 marks Rousseau's irrepressible passion for Countess Sophie d'Houdetot. It is a well-known fact that Rousseau wrote the Nouvelle Heloïse precisely in the attempt to overcome the subjective and objective difficulties of his unrequited love (Forni Rosa 2012, 7-17). Rousseau must resign himself to enjoying the Countess' friendship, because this is the only way in which he can settle the dispute between passion and virtue without giving up Sophie (Forni 2010, 183-193). The six letters that illustrate the evolution of the relationship between Rousseau and Sophie d'Houdetot probably were never mailed, but they are written with care, probably with an eye to publication (Rousseau 2012, XVII, 327). The fourth and fifth letters are especially important for the history of the Profession of Faith, since Rousseau has inserted passages from them into the Vicar's speech ${ }^{11}$.

In the fifth letter, Rousseau begins by remarking that the entire morality of man is in his intention. No action is good and just if the person doing it does not feel he must do it because it is good and just. Good actions leave in the actor a feeling of happiness and generate an instinctive inclination to approval in those witnessing their performance. The opposite is true for bad actions. This proves that the principle of goodness is present in the hearts of all men. In fact, authors of crimes in other circumstances generally show they possess a sensitive and good heart. Despite the "prodigious variety" of customs and cults in the nations of the world, one will find the same principles of justice and honesty everywhere (Rousseau 2012, XVII, 358-359). Rousseau shows, against the inertia and immorality deriving from scepticism, that among the pagans vice was admitted in the Olympus, but not in the human beings (Rousseau 2012, XVII, 360-361).

In their intellectual judgement, men are influenced by fortuitous conditionings and associations, by custom and by the knowledge they have acquired, but in the field of morals, they are absolutely autonomous: in this case the power of the innate maxims is such as to drive us in any case to judge our actions and those of others based on the same principles that God has given mankind. However, Rousseau laments, this proof regarding the original and innate aspect of moral conscience is overshadowed by the interventions of many philosophers who assert that the mind is a tabula rasa

${ }^{11}$ P.-M. Masson added the last two letters as an annex to his critique of the Profession de foi $d u$ Vicaire savoyard, Fribourg et Paris (Masson 1914, 479-499). 
and that it contains nothing but the contents corresponding to the ideas acquired through experience. Thus they are forced to deny the irrefutable proof of a conformity that is striking and contrasts with the diversity of customs. The feelings that nature has given us protect us and guarantee our very survival: love of oneself, fear of pain and of death, desire for well-being (Rousseau 2012, XVII, 362). Now, since man is a sociable being by his nature, or at least made to become so, he can be so only by means of innate feelings relative to his species ${ }^{12}$. In conclusion, the original moral conscience stems from the moral system that forms by means of the double relation of each human being to himself and to his fellow humans (Rousseau 2012, XVII, 363).

\section{The Profession of Faith of the Savoyard Vicar: the internal miracle}

The Profession of Faith is the confession of an itinerary in search of truth. The starting point is a state of doubt and uncertainty that, although Descartes considers it indispensable in the investigation of truth, Rousseau finds extremely disquieting, even immoral because it is «only the selfinterest of vice or laziness of soul which leaves us in it» (Rousseau 2012, VIII, 676). As in the Moral Letters, Rousseau confesses he feels that the doubt regarding what is most dear to him is «too violent a state for the human mind» (Rousseau 2012, VIII, 677). Permanent doubt is a pathological condition that the spirit spontaneously abandons to decide to take a direction. Rousseau confesses that he has found in the books of philosophers all of the misery of men driven not by the love of truth but by feelings of conceit, by the wish to show off, because in the general system of opposing theses «the most essential point is to think differently from the rest of the world» (Rousseau 2012, VIII, 678). The guide of philosophers once again proves itself to be inconsistent, unreliable and even harmful when it hinders the acquisition of urgent and essential decisions. One must therefore choose a different guide. The first truth that Rousseau perceives and to which he feels he must submit is the following: "I exist, and have senses whereby I am affected» (Rousseau 2012, VIII, 681). Immediately after having stated a starting point based on Condillac's sensism, however, Rousseau once again proposes the Descartian distinction between active and passive, inner life and the external world. The existence of others external to me is provided to me by the senses, such that I am certain of the existence not only of myself but also of the universe, and I perceive I am endowed with an active power capable of comparing objects and therefore of judging.

12 Here Rousseau implicitly contradicts his statements on the state of nature and on sociability we find in the second Discourse and in the Social Contract. 
In the search for truth, the Vicar puts forth an anthropological dualism that corresponds to the constitution of a sensitive and passive being that is but also active and intelligent. The distinction between communicated and spontaneous motion corresponds to the same dualism of active and passive. The first motion characterises matter, that moves only by means of an external motion; the second motion belongs to the spiritual beings, that move on their own. Motion and matter are separate. The two substances come together in the human being, in a way that Rousseau finds incomprehensible, but that it is not worth investigating. Thus, all of the questions arisen with regard to the relationship between physical and psychic within a Cartesian context appear to the Vicar as futile and negligible, as well as beyond man's limited capabilities, and therefore insoluble. The inanimate bodies of material nature act only if moved by a will, such that it is necessary to hark back to the first cause, a will that animates the universe: this is the first article of faith. But the order by which matter is moved by will, the fact that everything happens according to certain laws, brings me perforce to believe that that will also displays intelligence: this is the second article of faith. The two articles are all I know about the world with certainty (Rousseau 2012, VIII, 691). The third article of faith states the spiritual character of man and his freedom. Freedom is perceived as immediate proof with regard to one's self as soon as one acts and, by acting, one intuits the match or the mismatch between our action and the principles that God Himself has placed into our hearts. Feeling dragged in two opposite directions, torn and split between the good he knows and the evil he commits, man understands he is not one and, at the same time, that his true essence is spirit, because he perceives himself as a will independent from the senses, and therefore free.

Freedom is the determination of a being to act by virtue of a principle it gives himself. Freedom implies obedience to a law that the agent enforces upon himself. Therefore, the evil a man commits must be ascribed exclusively to himself. Indeed, moral evil is the most important of all evils, because physical evil derives from man's errors or vices, or can even become a good when related to totality (Rousseau 2012, VIII, 700-703). God is not at all responsible for the evil committed by man. He has given man freedom but is not responsible for man's abuses. Virtue has such a great value that the joy it brings is above any other. The immaterial soul may survive the body and this justifies the desire of the just man to find in the afterworld the joy he has deserved. There are many things that the man's reason cannot grasp, such as the infinite, for example, or the survival of the soul after death, and God's essence. The Vicar laments the incapacity of his soul to embrace the idea of infinity and eternity (Rousseau 2012, VIII, 709). The knowledge of good, 
however, does not depend on an abstract search for the foundations of morality, but rather on the intuitive certainty, on the immediate evidence with which each one of us finds within himself the universal and unchangeable precepts of conduct.

Here as elsewhere, Rousseau reminds his Moral Letters to Sophie d'Houdetot: the morality of our actions is not taught us by an authority or by philosophical arguments, but is established solely by our judgement, since the decisive element of the moral action is its intention. Every action accomplished is good and just if one feels one should accomplish it for the only reason that it is good and just (Rousseau 2012, VIII, 714). The notions of good and evil are impressed in the hearts of all men, the voice of conscience speaks incessantly also to the wicked and to all those who, driven by ambition and by vanity, are less inclined to listen. As in the Moral Letters before, Rousseau once again opposes the endless variety of customs, cults and usages to the substantial identity of moral maxims, a sort of moral instinct or feeling that demonstrates the fundamental unity of the human race in every era and at every latitude. The existence of an «innate principle of justice and goodness, by which, in spite of our own maxims, we approve or condemn the actions of ourselves and others» (Rousseau 2012, VIII, 715) ${ }^{13}$ definitely refutes the radical moral relativism that certain scholars insist on adopting as a criterion for judging not only exterior customs and cults but morality as well, therefore negating the singleness of conscience. The vanity of human opinions and the desire to show off transform the search for truth into a pretext for triumphing over their adversaries, in a confrontation where the prize is not the conquest of truth but rather fame and distinction. The difficulty in conquering virtue depends on the yoke of the senses and of the body, to which man's soul is chained. The submission of the soul to the body, given the heterogeneity of the two terms, is inexplicable because we know not God's plans, but it is a very well founded theory that, should man have remained entirely freed of any conditioning and should his existence have been perfectly compliant with moral order, he would have been happy, although his happiness would have been without "the glory of virtue". In this way, instead, the man that attains virtue by overcoming the adversities that drag him in the opposite direction shall be superior to angels (Rousseau 2012, VIII, 723).

The need of an obstacle for the achievement of virtue and moral order in the world transforms the dependence of the rational soul from the body, per se incomprehensible, into the necessary condition for achieving that

\footnotetext{
${ }^{13}$ Knowledge of good and evil is not demonstrative but intuitive. The notions of good and evil are universal and necessary, evident and cogent. Intuitive knowledge, which John Locke places above demonstrative knowledge, is as immediately certain as it is unobjectifiable on a theoretical level.
} 
morality which is at the same time essential to and specific of humanity. In this, Rousseau anticipates Kant: without the obstacle of sensitive inclination, that per se is the negation of morality, it would be impossible to achieve any virtue. The world is as it should be and the only evil that the Vicar can disapprove of is that which he himself would commit. The Vicar feels that he has absolutely nothing to ask of a God that has given him a priceless gift, freedom, because this would mean wanting to change that perfection that he himself recognizes in creation. The miracle by which God could intervene to gratify those who implore him assumes that the world is imperfect and that God wishes to and can fix it with an ad hoc action, making an exception to the laws of nature according to an entirely arbitrary criterion, totally unworthy of divine majesty. For this reason the Vicar, in a converging manner with respect to Voltaire's analysis, clearly sees the inconsistency between the perfection of God's work and God's miraculous intervention in support of anyone (Rousseau 2012, VIII, 732-733).

The Vicar's faith in reason is justified by the fact that God Himself has placed the knowledge of God in the hearts of men. Reason - the set of senses, conscience and judgement - immediately understands the essential ideas of divinity. Natural religion consists in knowing and serving God according to the teachings He himself imparts to my spirit. Compared to the true religion, the highest one, the revealed religions with their useless and arbitrary dogmas do nothing more than obscure the superior divine dignity, adding strange cults and absurd elements, the sole result of which is the triggering of disputes and sanguinary conflicts between the various sects. Had the peoples of the earth limited themselves to listening to the voice of God directly from their hearts, there would have been but one religion on earth.

The Vicar explains well why there cannot be a true revealed religion that excludes all of the others: should God order one religion to be the only true one, establishing eternal damnation for those who do not follow it, he would have had to send irrefutable and unequivocal signs to all men, none excluded, to allow them to perceive it as the only true religion, because should even only one man not be reached by these signs and become persuaded of their truth, it would be enough to conclude that the God of this religion is a monster of cruelty and injustice (Rousseau 2012, VIII, 734-735). In communicating the truth to mankind, God must prefer effective and reliable methods and means, unless $\mathrm{He}$ wishes to receive negative opinions that are unworthy of His name. The best way is not by means of miracles, of exterior signs, but rather by means of the internal voice. The feeling, the voice that speaks endlessly, is the only way in which God can speak to men with the certainty that they will listen, that they receive the sign, even if then 
their actions betray the truth announced by God to their hearts. In Rousseau, the voice of conscience is an internal miracle, just like for Locke the signs of Jesus are external miracles. Locke denies the existence of invisible miracles since by definition a miracle is an event that must impress the senses: a miracle is a manifestation of the divine will that suspends the laws of nature.

No book is worthy of being compared to nature, with the exception of the Gospel, that tells of life and refers the words spoken by Jesus, the wisest and most virtuous man to ever have lived, and indeed «if the life and death of Socrates are those of a sage, the life and death of Jesus are those of a God» (Rousseau 2012, VIII, 750). The history of the Gospel is certainly not fiction, because the Gospel indeed contains characters «so striking and inimitable, that the inventor would be a more astonishing character than the hero» (Rousseau 2012, VIII, 750). The Gospel contains the maxims of natural religion, as well as incredible things contrary to reason and that a reasonable man cannot admit. The divine part of the Gospel is that which is in harmony with the precepts of the heart, with the universal notions of moral conscience. This harmony with the heart, i.e. the reasonableness of Jesus' words, and certainly not the miracles, is the proof of their divine origin.

This internal acknowledgement is the real divine cult because it allows to overcome the purely ritualistic dimension of religion and to faithfully transform the contemplated truth into conduct (Rousseau 2012, VIII, 751). The Vicar not only warns against the dogmatism and formalism of revealed religions - i.e. against that apparatus that is entirely unjustified because it does not match any truth according to its primary source, the heart of man - but also against intellectualistic investigation and philosophical disputes, against the rather cynical unscrupulousness with which allegedly illuminated intellects trample and destroy everything that men respect (Rousseau 2012, VIII, 757). Thus two are the abuses that drive man away from the source of truth, from his heart: on the one side the dogmatic apparatus of religions and the system of signs that is charged with the task of proving the divine character of revelation; on the other the extreme exercise of free thought, the excess of rational investigation and the obstinacy of the intellect that divides men without increasing their knowledge.

\section{The letter to Monsieur de Franquières}

The letter to $M$. de Franquières, a character of whom we know practically nothing, is dated January $15^{\text {th }}, 1769$ and seems to be the reply to a previous letter sent by the recipient to Rousseau. In it Rousseau confesses his scepticism with regard to his correspondent's still ongoing inquiries about the Author of things. Rousseau reiterates here his distinction between physical evil and moral evil. The physical evils of which men lament physical pain, the fear of death, death itself - are naught but the consequence of the institutions and of the weakness that civilisation has artificially 
introduced into the life of every individual. Physical evils are the work of man, of the process of civilisation, and therefore are nothing per se. Even moral evil, the only deformity of the universe worthy of being taken into consideration, is exclusively the work of man, since God simply created man free and cannot be held responsible for the abuses man makes of his freedom. God - infinitely good, wise and powerful - has no part in the evil of the world. Rousseau implicitly picks up here the considerations he used in the fragment Sur Dieu and in the Lettre à François-Marie Arouet dit Voltaire (18 août 1756).

Man is entirely responsible for the only true evil, moral evil. The origin of evil finds its explanation if one admits the eternal coexistence of two principles, an active one, that is God himself, and a passive one, that is matter. God combines and changes matter with all of his power - a matter that, however, God has not created and cannot destroy (Rousseau 2012, VIII, $512)^{14}$. The very existence of God has a decisive moral significance. It is true that all cult forms seem unrighteous, false, hypocritical and tyrannical, but this does not disprove the existence of God, and indeed it makes it all the more true and necessary, because to remove the belief in God from the hearts of men means to destroy all virtue. God is the interior witness of each one of our actions, He in whom one can acknowledge the power to read within our heart the intention of putting to good use the freedom that He himself gave man (Rousseau 2012, VIII, 746).

\section{References:}

1. Z. Bauman, Z. - Dessal, G. (2015). El retorno del péndulo. Sobre psicoanálisis y el futuro del mundo liquido, 2014, trad. it., Il ritorno del pendolo. Psicoanalisi e futuro del mondo liquido, edited by R. Mazzeo, Erickson, Trento 2015.

2. Burgelin, P. (1952). La philosophie de l'existence de J.-J. Rousseau, Paris 1952, cit. in J.-J. Rousseau, Euvres Complètes, édition publiée sous la direction de Bernard Gagnebin et Marcel Raymond, Bibliothèque de la Pléiade, Gallimard, Paris, vol. IV.

3. Courtois, L.-J. (1969). Chronologie critique de la vie et des ouvres de J.-J. Rousseau, cit. in J.-J. Rousseau, Euvres Complètes, édition publiée sous la direction de Bernard Gagnebin et Marcel Raymond, Bibliothèque de la Pléiade, Gallimard, Paris, vol. IV.

\footnotetext{
${ }^{14}$ The same dualism is anticipated in the Profession of Faith. Here Rousseau takes up a position with regard to an issue, whether the world was created or is eternal, that in the Profession of Faith he had declared he would ignore (Rousseau 2012, VIII, 694). In the Letter to M. de Franquières, the independence of matter from God himself is declared, within the context of an ontological dualism that could however, in turn, pose many unresolved problems.
} 
4. Dupuy, J.-P. (2007) Pétite Métaphysique des tsunamis, Éditions du Seuil Paris.

5. Forni Rosa, G. (2010). «L'amore impossibile. Passione e matrimonio nella Nuova Eloisa», in G. Forni Rosa, L'amore impossibile. Filosofia e letteratura da Rousseau a Lévi-Strauss, Marietti 1820, Genova-Milano.

6. Forni Rosa, G. (2012). «Introduzione» a J.-J: Rousseau, Lettere morali, Marietti 1820, Genova-Milano.

7. Masson, P.-M. (1914). Profession de foi du Vicaire savoyard, Fribourg et Paris.

8. Masson, P.-M. (1970). La religion de Jean-Jacques Rousseau, Slatkine Reprints, Genéve 1970, reprint of the 1916 edition.

9. Migne, J.P. (1841-1864). Patrologiae cursus completes, series latina, Paris 1841-1864, vol. 7, coll. 77-146, 121A-B.

10. Neiman, S. (2003). Evil in modern thought: an Alternative History of Philosophy, Princeton University Press.

11. Rousseau, J.-J. (1969). OC (Oeuvres complètes 1959-1995, Édition publiée sous la direction de Bernard Gagnebin et Marcel Raymond avec la collaboration de Samuel Baud-Bovy, Brenno Boccadoro, Xavier Bouvier, Marie-Élisabeth Duchez, Jean-Jacques Eigeldinger, Sidney Kleinman, Olivier Pot, Jean Rousset, Pierre Speziali, Jean Starobinski, Charles Wirz et André Wyss - Collection Bibliothèque de la Pléiade, Gallimard, Paris).

12. Rousseau, J.-J. (2012). Euvres complètes, sous la direction de Raymond Trousson et Frédéric S. Eigeldinger, Éditions Slatkine, Genève, Éditions Champion, Paris.

13. Tagliapietra, A. (2004). Introduzione. La catastrofe e la filosofia, in Voltaire, Rousseau, Kant, Sulla catastrofe. L'illuminismo e la filosofia del disastro, introduzione di A. Tagliapietra, traduzioni di S. Manzoni ed E. Tetamo, con un saggio di P. Giacomoni, Bruno Mondadori, Milano. 